\title{
Nuclear Engineering Academic Programs Survey, 2002 Data
}

\section{SURVEY UNIVERSE}

The survey includes degrees granted between July 1, 2001 and June 30, 2002. Enrollment information refers to the fall term 2002. Thirty-five academic programs were in the survey universe and all responded (100\% response rate). One of the 35 programs reported that it was discontinued after the 2001-2002 academic year. Also, two programs were discontinued after the previous academic year (2000-2001) and were not included in 2002 survey.

\section{DEGREE DATA}

Bachelor's Degrees. The number of B.S. degrees granted in 2002 by nuclear engineering programs participating in the Department of Energy, Office of Nuclear Energy, Science and Technology Fellowship and Scholarship program (NEST F\&S) was the highest number reported over the last five years. This was a substantial increase (44\%) over the number of B.S. degrees granted in 2001 (which was the lowest number in over a decade). (See Table 1, part A.) The number of B.S. degrees granted in 2002 by all nuclear engineering programs also increased over 2001. (See Table 1, part B.) Nuclear engineering majors accounted for $83 \%$ of all B.S. degrees with the remaining $17 \%$ in nuclear engineering option programs.

Graduate Degrees. For nuclear engineering programs participating in the NEST F\&S, the number of both masters' and doctorate degrees granted in 2002 declined from 2001. (See Table 1, part A.) Almost all M.S. and Ph.D. degrees are granted by programs in the NEST F\&S, thus the number of graduate degrees granted by all nuclear engineering programs followed the same trend as for the NEST F\&S programs. (See Table 1, part B.) Nuclear engineering majors accounted for all of the graduate degrees except two doctorate degrees.

Table 1. Nuclear Engineering Degrees, 1998-2002

A. DOE, NEST Fellowship and Scholarship Nuclear Engineering Programs:

\begin{tabular}{cccc} 
& \multicolumn{3}{c}{ Degrees } \\
\cline { 2 - 4 } Year & B.S. & M.S. & Ph.D. \\
\hline 2002 & 153 & 117 & 65 \\
2001 & 106 & 132 & 80 \\
2000 & 143 & 126 & 68 \\
1999 & 132 & 126 & 74 \\
1998 & 143 & 144 & 89
\end{tabular}

B. Total All Nuclear Engineering Programs:

\begin{tabular}{cccc} 
& \multicolumn{3}{c}{ Degrees } \\
\cline { 2 - 4 } Year & B.S. & M.S. & Ph.D. \\
\hline 2002 & 195 & 130 & 67 \\
2001 & 120 & 145 & 80 \\
2000 & 159 & 133 & 74 \\
1999 & 199 & 142 & 86 \\
1998 & 222 & 160 & 98
\end{tabular}




\section{Enrollments and Short Term Outlook for Degree Trends}

The enrollment of undergraduate nuclear engineering majors has increased substantially over the last two years indicating a continuing increase in the number of bachelor's degrees. The enrollment of graduate students increased in the fall 2002 after remaining stable from 2000 to 2001, and decreasing from 1998 to 2000. This enrollment trend indicates an increasing number of graduate degrees over the next few years.

\section{Employment or Postgraduate Study Data}

Among the B.S. degree graduates, the most common post graduation activities were: $31 \%$ continued study, $17 \%$ U.S. military active duty, and $10 \%$ nuclear electric utilities employment. Less than $3 \%$ were still seeking employment at the time of the survey response. (See Table 2.)

Table 2. Employment or Postgraduate Study Information

\author{
Continued study \\ Academic institution, U.S. \\ Federal government \\ DOE contractor \\ State and local government \\ Nuclear utilities, U.S. \\ Other industry, U.S. \\ Foreign employment \\ U.S. military \\ Other employment \\ Seeking employment \\ Unknown and not reported
}

Totals

\begin{tabular}{rrr} 
B.S. & M.S. & Ph.D. \\
\hline 61 & 39 & 11 \\
8 & 2 & 5 \\
12 & 11 & 6 \\
4 & 13 & 20 \\
3 & 2 & 0 \\
20 & 14 & 7 \\
11 & 10 & 9 \\
0 & 10 & 0 \\
34 & 13 & 1 \\
3 & 5 & 0 \\
5 & 1 & 2 \\
34 & 10 & 6 \\
195 & 130 & 67
\end{tabular}

Among the M.S. degree graduates, the most common post graduation activities were: $30 \%$ continued study, $11 \%$ nuclear electric utilities employment, and $10 \%$ for both DOE contractor employment and U.S. military active duty. Less than $1 \%$ was still seeking employment at the time of the survey response.

Among the Ph.D. degree graduates, the most common post graduation activities were: $30 \%$ DOE contractor employment, $16 \%$ continued study, and $13 \%$ other industry employment. Three percent were still seeking employment at the time of the survey response.

\section{Foreign National Data}

Less than $4 \%$ of the B.S. degree recipients were non-U.S. citizens. Approximately $40 \%$ of both the M.S. degree recipients and Ph.D. degree recipients were non-U.S. citizens. 
Table 3. Nuclear Engineering Degrees, 2002, by Academic Institution

\begin{tabular}{|c|c|c|c|c|c|c|}
\hline \multicolumn{2}{|c|}{$\begin{array}{l}\text { NEST F\&S Status } \\
\text { as of May } 2003\end{array}$} & \multirow[b]{2}{*}{ Name of Institution } & \multirow[b]{2}{*}{$\underline{\text { State }}$} & \multicolumn{3}{|c|}{$\begin{array}{c}\text { Degrees, July } 12001 \text { - } \\
\text { June 30, } 2002\end{array}$} \\
\hline Scholarship & Fellowship & & & B.S. & M.S. & Ph.D. \\
\hline & & University of Arizona & $A Z$ & 1 & 0 & 0 \\
\hline Yes & Yes & University of California, Berkeley & CA & 6 & 2 & 1 \\
\hline Yes & Yes & University of Florida & $\mathrm{FL}$ & 6 & 14 & 0 \\
\hline Yes & Yes & Georgia Institute of Technology & GA & 5 & 2 & 4 \\
\hline \multirow[t]{2}{*}{ Yes } & Yes & Idaho State University & ID & 0 & 1 & 1 \\
\hline & & University of Idaho & ID & 0 & 0 & 0 \\
\hline Yes & Yes & University of Illinois, Urbana & IL & 6 & 4 & 4 \\
\hline \multirow[t]{2}{*}{ Yes } & Yes & Purdue University & IN & 16 & 6 & 3 \\
\hline & & University of Notre Dame & IN & 4 & 0 & 0 \\
\hline \multirow[t]{2}{*}{ Yes } & Yes & Kansas State University & KS & 3 & 2 & 0 \\
\hline & & Louisiana State University & LA & 0 & 0 & 0 \\
\hline Yes & Yes & Massachusetts Institute of Technology & MA & 5 & 14 & 10 \\
\hline \multirow[t]{2}{*}{ Yes } & & University of Massachusetts, Lowell & MA & 2 & 3 & 0 \\
\hline & & University of Maryland, University College* & MD & 16 & 0 & 0 \\
\hline \multirow[t]{2}{*}{ Yes } & Yes & University of Maryland, College Park & MD & 2 & 2 & 3 \\
\hline & & University of Maine & ME & 2 & 0 & 0 \\
\hline Yes & Yes & University of Michigan, Ann Arbor & MI & 11 & 11 & 12 \\
\hline Yes & Yes & University of Missouri, Columbia & MO & 0 & 2 & 2 \\
\hline Yes & & University of Missouri, Rolla & MO & 6 & 1 & 1 \\
\hline Yes & Yes & North Carolina State University & $\mathrm{NC}$ & 9 & 8 & 2 \\
\hline \multirow[t]{2}{*}{ Yes } & Yes & University of New Mexico & NM & 3 & 4 & 0 \\
\hline & & Cornell University & NY & 0 & 2 & 0 \\
\hline \multirow[t]{3}{*}{ Yes } & Yes & Rensselaer Polytechnic Institute & NY & 28 & 4 & 2 \\
\hline & & United States Military Academy & NY & 13 & 0 & 0 \\
\hline & & Air Force Institute of Technology & $\mathrm{OH}$ & 0 & 7 & 1 \\
\hline Yes & Yes & Ohio State University & $\mathrm{OH}$ & 0 & 4 & 2 \\
\hline Yes & Yes & University of Cincinnati & $\mathrm{OH}$ & 0 & 5 & 3 \\
\hline Yes & Yes & Oregon State University & OR & 4 & 4 & 0 \\
\hline \multirow[t]{2}{*}{ Yes } & Yes & Pennsylvania State University & PA & 12 & 5 & 4 \\
\hline & & Tennessee Technological University & TN & 0 & 0 & 0 \\
\hline Yes & Yes & University of Tennessee, Knoxville & $\mathrm{TN}$ & 9 & 7 & 0 \\
\hline \multirow[t]{2}{*}{ Yes } & Yes & Texas A\&M University, College Station & $\mathrm{TX}$ & 12 & 6 & 1 \\
\hline & Yes & University of Texas, Austin & $\mathrm{TX}$ & 6 & 6 & 4 \\
\hline Yes & Yes & University of Utah & UT & 3 & 0 & 4 \\
\hline Yes & Yes & University of Wisconsin, Madison & WI & 5 & 4 & 3 \\
\hline & & Totals & & 195 & 130 & 67 \\
\hline
\end{tabular}

*Program discontinued after 2002. 
Prepared by: Science and Engineering Education, Oak Ridge Institute for Science and Education, October 2003.

This document describes activities performed under contract number DE-AC05-00OR22750 between the U.S. Department of Energy and Oak Ridge Associated Universities.

All opinions expressed in this report are the author's and do not necessarily reflect policies and view of the U.S. Department of Energy or the Oak Ridge Institute for Science and Education.

The Oak Ridge Institute for Science and Education (ORISE) is a U.S. Department of Energy facility focusing on scientific initiatives to research health risks from occupational hazards, assess environmental cleanup, respond to radiation medical emergencies, support national security and emergency preparedness, and educate the next generation of scientists. ORISE is managed by Oak Ridge Associated Universities. 